DOI : $10.14746 / \mathrm{pp} .2014 .19 .1 .18$

\title{
Maria GIEDZ
}

Gdańsk

\section{Kurdowie we współczesnych społecznościach Bliskiego Wschodu}

\begin{abstract}
Streszczenie: Bliski Wschód jest regionem charakteryzującym się ogromną różnorodnością zarówno religijną, narodowościową jak i etniczną. W tym bliskowschodnim tyglu społeczeństw wyróżniają się Kurdowie, szacowany na 45 milionów osób naród, który do tragedii, jaka rozegrała się wiosną $1991 \mathrm{r}$. był niezauważalny. Do amerykańskiej interwencji na Irak, Kurdowie we wszystkich czterech krajach, w których przyszło im mieszkać, byli traktowani jako obywatele 2-giej kategorii. Momentem przełomowym stał się rok 2003, kiedy to Kurdów zaczęto postrzegać jako naród, który ma prawo do samostanowienia. Wydarzenia po 2003 r. doprowadzily do kuriozalnej sytuacji, w której ludność z marginesu staje się ważnym partnerem na międzynarodowej scenie politycznej. W Iraku Kurdowie pelnią funkcję katalizatora pomiędzy zwaśnionymi, muzulmańskimi grupami. W kontekście „Arabskiej Wiosny” i wydarzeń w Syrii, stanowią dla rządów Turcji i Syrii kartę przetargową, ale jednocześnie to im powierza się działania integracyjne. Tworzy się niezwykle interesująca sytuacja. Dotychczas poniżana spoleczność staje się poważanym narodem, który może mieć wpływ na rozwiązanie konfliktów na Bliskim Wschodzie.
\end{abstract}

Słowa kluczowe: Kurdystan, Kurdowie, Region Kurdystanu, Barzani, Bliski Wschód, Syryjska Rewolucja

\section{Wstęp}

D liski Wschód jest regionem charakteryzującym się ogromną różnorodnością zarówno religijna, narodowościową, jak i etniczna. Jednak przeciętnemu Europejczykowi teren ten kojarzy się zaledwie $z$ trzema religiami i trzema, może czterema narodami.

Odrzucając stereotypowe postrzeganie Bliskiego Wschodu widzimy w tym regionie kolebkę wszystkich, funkcjonujących do dzisiaj, monoteistycznych religii, czyli zaratusztrianizmu i opartego na nim, powstałego w czasach późniejszych jezydyzmu ${ }^{1}$, judaizmu, chrześcijaństwa, niestety podzielonego, a przez niektóre społeczności traktowanego wy-

${ }^{1}$ Baba Cawîs (Ojciec Czałis), główny opiekun jedynej świąyni jezydów w Lalish (Region Kurdystanu - północny Irak, okolice Mosulu) i członek Rady Religijnej Jezydów w rozmowie z autorką 12.06.2013 r., twierdzil, że to jezydyzm jest pierwszą monoteistyczną religią na świecie, a zaratustrianizm jest jego pochodną. Niestety wszystkie informacje i dokumenty, w tym święte księgi zostały doszczętnie zniszczone przez muzułmanów. Jezydzi mieli i mają tylko jedną świątynię, podobnie jak w Starym Testamencie Żydzi, gdzie przechowywano przez setki lat zapiski dotyczące prawd wiary. Wraz z ekspansją arabskich muzułmanów na tereny kurdyjskie, między VII a IX w., Dolina Lalish i znajdująca się w niej świątynia zostala doszczętnie zniszczona. Jej odrodzenie już w innej, bardziej skromnej formie w oparciu o szyizm (jeden $z$ dwóch głównych nurtów islamu) i chrześcijaństwo nastapilo dopiero w XII-XIII wieku. 
miennie z narodowością, np. asyryjską, chaldejską i islamu w jego odmianach, z którego wywodzą się grupy czasem uznawane za odrębne religie, a również utożsamiane z grupą etniczna jak np. Druzowie czy Alawici.

Jeśli chodzi o narody żyjące na Bliskim Wschodzie, to różnorodność jest tak duża, że trudno je wszystkie policzyć. Stereotypowe myślenie koncentruje się na Żydach i Arabach oraz Turkach i Persach. A przecież samych tureckich grup narodowych i etnicznych na Bliskim Wschodzie występuje ponad trzydzieści. Zgodnie $\mathrm{z}$ obowiązująca jeszcze konstytucją turecką z 1982 r. (art. 66), Turcja jest państwem jedno narodowym. Dopuszcza się istnienie jedynie takich narodów jak Grecy, Ormianie, Żydzi. Rzeczywistość jest jednak inna, żyją tam, obok Turków, m.in. Czerkiesi, Łazowie, Jurucy, Tatarzy, Arabowie, Cyganie, a nawet Polacy...

W tym ogromnym bliskowschodnim tyglu społeczeństw wyróżniają się Kurdowie, spory, szacowany na 45 milionów osób naród ${ }^{2}$, który do tragedii, jaka rozegrała się wiosną 1991 r. był prawie niezauważalny. Praktycznie do 2003 r., czyli do amerykańskiej interwencji na Irak Kurdowie we wszystkich czterech krajach, w których przyszło im mieszkać, notabene od stuleci na ich własnej ziemi, bowiem terytoria kurdyjskie traktatem w Lozannie z 24 lipca 1923 r. (Traty) zostały rozdzielone na: Turcje, Persje (Iran), Mandat Brytyjski, czyli dzisiejszy Irak i Mandat Francuski, obecną Syrię, byli traktowani jako obywatele 2-giej kategorii. W Syrii część z nich, szacowana na około 350 tys. osób, nadal w ogóle nie ma obywatelstwa.

Momentem przełomowym stał się rok 2003, kiedy to Kurdów zaczęto postrzegać jako samodzielny naród, który ma prawo do samostanowienia. Wydarzenia po 2003 r. doprowadziły do kuriozalnej sytuacji, w której ludność z marginesu staje się ważnym partnerem na międzynarodowej scenie politycznej.

Kurdowie zaczynają odgrywać wiodącą rolę wśród społeczności bliskowschodnich. W Iraku pełnią funkcję katalizatora pomiędzy zwaśnionymi, muzułmańskimi grupami. W kontekście „Arabskiej Wiosny” i wydarzeń w Syrii, stanowią dla rządów Turcji i Syrii kartę przetargową, ale jednocześnie to im powierza się działania integracyjne. Tworzy się niezwykle interesująca sytuacja, niestety w polskiej literaturze naukowej, nie mówiąc już o środkach masowego przekazu, prawie niedostrzegana.

Wszystko wskazuje na to, że rządy wielu państw będą musiały zaakceptować Kurdów, nie tylko jako nowego gracza na arenie politycznej, ale partnera, a przede wszystkim „stabilizatora” bliskowschodnich konfliktów.

Niniejszy artykuł jest próbą wyjaśnienia tej zawiłej sytuacji, w której dotychczas poniżana społeczność staje się poważanym narodem. Narodem, który może mieć wplyw na

\footnotetext{
${ }^{2}$ Masud Barzani, prezydent Regionu Kurdystanu, autonomicznej części Kurdystanu w Północnym Iraku w rozmowie z autorką w czerwcu 2005 r. twierdził, że Kurdów na całym świecie mieszka około 40-45 mln; Kemal Kerkuki, marszalek kurdyjskiego parlamentu Regionu Kurdystanu, rozmawiając z autorką we wrześniu 2010 r. podał, że Kurdów jest 43 mln; natomiast Şivan Perwer, kurdyjski bard i przywódca duchowy mieszkający na uchodźstwie szacuje Kurdów na ok. $50 \mathrm{mln}$ osób (wywiad przeprowadzony przez autorkę we wrześniu 2011 r.). Ustalenie liczebności Kurdów jest trudne, gdyż nikt nie prowadzi statystyk. Obecnie można jedynie podać, i to w przybliżeniu, ilu Kurdów mieszka w Regionie Kurdystanu, opierając się na ilości oddanych głosów podczas wyborów do parlamentu irackiego, które odbyly się 7 marca $2010 \mathrm{r}$.
} 
rozwiązanie konfliktów w państwach Bliskiego Wschodu. Oparty jest w znacznym stopniu na empirycznych doświadczeniach autorki, która zna tereny kurdyjskie. Autorka stosuje głównie metody jakościowe, w tym badania terenowe, czyli wywiady przeprowadzone z przedstawicielami partii kurdyjskich, a także mieszkającą na terenach kurdyjskich ludnością chrześcijańską i muzułmańską, ale nie kurdyjską. Stosuje również obserwację uczestnicząca.

W polskiej literaturze naukowej od końca lat 60-tych XX w. ukazało się kilka publikacji poświęconych narodowi kurdyjskiemu, przedstawiając ten naród w różnych aspektach. Mamy prace autorów kurdyjskich w thumaczeniu, np. autorstwa zamordowanego w Wiedniu irańskiego Kurda Rahmana Ghassemlou (Ghassemlou, 1969), Amira Grigiesa (Grigies, 1997), czy mieszkającego i pracującego w Polsce Fuada Jomma (Jomma, 2001), a także interesujące opracowanie o irackim Kurdystanie Krzysztofa Lalika (Lalik, 2009). Sztandarową pozycją jest praca nieżyjącego już krakowskiego profesora Leszka Dzięgiela (Dzieggiel, 1992). Ukazały się też dwie monografie autorki niniejszego opracowania (Giedz, 2002; Giedz, 2010). Najnowsza polska publikacja Joanny Bocheńskiej, chociaż skupiona głównie na kurdyjskiej literaturze, jest również próbą podejścia kompleksowego do problemu kurdyjskiego (Bocheńska, 2011a). To właśnie Bocheńska wskazuje na kluczową rolę Kurdów w odniesieniu do przyszłości Bliskiego Wschodu (Bocheńska, 2011b).

Większość publikacji obcojęzycznych zarówno autorów kurdyjskich, jak i zachodnich np. Susan Meiselas (Meiselas, 2008), Caladeta Bedirxana (Bedirxan, 1997), Bernarda Dorina (Dorin, 2005) skupia się przede wszystkim na omówieniu historii Kurdów, zaprezentowaniu ich martyrologii, życia społecznego czy sytuacji politycznej. Autorka wykorzystuje głównie najnowsze opracowania, niestety w większości publicystyczne, przede wszystkim anglojęzyczne, zwłaszcza te powiązane z wydarzeniami w Syrii, a także bliskowschodnie strony internetowe.

\section{Przyczyny zmian w postrzeganiu Kurdów}

Wydarzenia z 11 września 2001 r. i ogłoszona przez Stany Zjednoczone „wojna z terroryzmem" stały się podstawą w wyjaśnieniach wejścia wojsk amerykańskich, a następnie koalicyjnych do Iraku (Jureńczyk, 2010, s. 19-25). Inwazja na Irak rozpoczęła się 20 marca 2003 r., jednak, niemal w przededniu tego wydarzenia rząd Turcji odmówił udziału w wojnie, a także odmówił wpuszczenia wojsk amerykańskich na terytorium Turcji, co uniemożliwiło utworzenie frontu północnego ${ }^{3}$. Wówczas pomoc Amerykanom zaproponowali Kurdowie, którzy co prawda w przeszłości byli kilkakrotnie przez Amerykanów zdradzeni (Giedz, 2010, s. 163-166), ale uznali, że sytuacja jest na tyle poważna, iż ułatwili Amerykanom zajęcie strategicznych pól naftowych pod Kirkukiem i Mosulem, wykazując się brawurową akcją. Ułatwili im także podejście pod Bagdad od północy oraz przyczynili się do znalezienia i schwytania Saddama Husajna. Przyczynili się również do unieszkodliwienia organizacji terrorystycznej Ansar-al-Islam (Lalik,

\footnotetext{
${ }^{3} 1$ marca 2003 r. parlament turecki odrzucił umowę o wspólpracy z Pentagonem, dopuścił jedynie przelot samolotów alianckich przez tureckie terytorium (Lalik, 2009, s. 169; Jureńczyk, 2010, s. 46, 49; Giedz, 2010, s. 166).
} 
2009, s. 168). Kurdowie zapewne liczyli na amerykańską pomoc w utworzeniu samodzielnego państwa, oczywiście po zakończeniu wojny, jednakże zadowolili się usankcjonowaniem kurdyjskiej autonomii w północnym Iraku, którą rząd Iraku obiecywał im od kilkudziesięciu lat ${ }^{4}$. W praktyce autonomia ta funkcjonowała od połowy roku 1991, kiedy to w północnym Iraku utworzono strefę zakazu lotów dla lotnictwa irackiego, tzw. $\mathrm{Li}$ beration Zone, nazywaną też strefą ,, bezpiecznego nieba” (safe haven), powstałą na mocy 688 rezolucji Rady Bezpieczeństwa Organizacji Narodów Zjednoczonych (Lalik, 2009, s. 103; Tripp, 2009, s. 305).

Kiedy w marcu 2004 r. z inicjatywy wojsk okupacyjnych powstała tymczasowa Iracka Rada Zarządzająca, jej działania oparto na kurdyjskiej wizji państwa federalnego ${ }^{5}$, a w jej skład weszło m.in. 5 Kurdów. Dla Kurdów kluczową sprawą stało się stworzenie z Iraku państwa federacyjnego, niemniej w nieoficjalnym referendum przeprowadzonym wraz z wyborami parlamentarnymi w dniu 30 stycznia 2005 r., Kurdowie mieszkający w części autonomicznej w 98\% wypowiedzieli się za niepodległością Kurdystanu i oddzielenia go od Iraku (Lalik, 2009, s. 178; Kurdistan Referendum). Mimo że referendum nie miało żadnych prawnych konsekwencji, to fakt ten umocnił pozycję kurdyjskich liderów $\mathrm{w}$ późniejszych negocjacjach $\mathrm{z}$ arabskimi deputowanymi czy przedstawicielami rządu amerykańskiego. Pozycja Kurdów została również wzmocniona samymi wyborami, bowiem Kurdowie na 275 mandatów w irackim parlamencie uzyskali 75 mandatów, stając się drugą siłą polityczną w kraju (Katzman, 2006). Kolejnym sukcesem społeczności kurdyjskiej był wybór Kurda na prezydenta Iraku w dniu 6 kwietnia 2005 r. (Tarabani). Prezydentura Dżalala Talabaniego została przedłużona o kolejną kadencję, bowiem od kiedy prezydentem Iraku został Kurd i okazało się, że jego polityka nie jest jedynie prokurdyjska, Kurdów zaczęto doceniać. Przekonano się, że nie gardzą „,niewiernymi”, jak to czynią zarówno szyiccy, jak i sunnicy iraccy Arabowie, są lepiej od nich wykształceni i że mają dużo do zaoferowania obcemu kapitałowi oraz chętnie współpracują z zagranicznymi inwestorami.

W wyborach z 15 grudnia 2005 r. Kurdowie stracili 22 mandaty, ale ich pozycja nadal była bardzo wysoka, głównie dzięki zaangażowaniu się w tworzenie nowej irackiej konstytucji. Kurdowie są współautorami owej konstytucji, przyjętej 15 października 2005 r. (Giedz, 2010, s. 146-149), a można nawet powiedzieć, że sąjej głównymi konstruktorami. Dzięki Kurdom w owej konstytucji znalazł się zapis dotyczący dopuszczania kobiet do władzy i do obejmowania przez kobiety wyższych stanowisk ${ }^{6}$.

${ }^{4}$ Pierwsza informacja na temat przyznania irackim Kurdom autonomii pojawiła się 14 lipca 1958 r., w dniu obalenia monarchii i ogloszenia Republiki Irackiej (Nielubowicz, 1979, s. 43). Ową obietnicę o autonomii zaczęto realizować dopiero w $1970 \mathrm{r}$. i to na skutek toczącego się konfliktu iracko-irańskiego o Szatt-al-Arab. 11 marca 1970 r. doszło do podpisania słynnego „Marcowego Manifestu”, sygnowanego przez ówczesnego wiceprezydenta Iraku Saddama Husajna i kurdyjskiego przywódcę Mustafę Barzaniego - oryginalny tekst oraz jego thumaczenia znajduje się w: (Giedz, 2010, s. 231-237). Postanowień Manifestu rząd Iraku nie respektował, tym samym prawo o autonomii nie weszło w życie.

${ }^{5}$ Już w 2002 r. Kurdowie z uniwersytetu w Hawlerze (Erbil) opracowali projekt stworzenia z Iraku federacji kurdyjsko-arabskiej.

${ }^{6}$ Kurdowie naciskali, aby w irackiej konstytucji znalazł się zapis podkreślający równe prawa dla kobiet i mężczyzn w życiu publicznym, art. 37 i 41 irackiej konstytucji przyjętej przez referendum, które odbyło się 25.10.2005 r. (Iraqi Constitution). 
Trudno jest przedstawiać Kurdów jedynie w samych pozytywach. Jest to naród niezwykle podzielony, przez tysiąclecia funkcjonujący w grupach klanowych. Zamieszkuje tereny górzyste, gdzie od zawsze prowadzi się walkę z żywiołem natury, ale też z rodami z sąsiadujących dolin, chociażby o prawo do wypasania zwierząt. Stąd też postrzeganie Kurdów jako walecznych wojowników nie jest bezpodstawne. W czasach współczesnych owe klany rodowe przekształciły się w partie polityczne, często nawzajem ostro się zwalczające. Jednak i w tym przypadku Kurdowie wykazują dużą świadomość, a raczej dojrzałość polityczną.

Po usankcjonowaniu, mocą irackiej konstytucji, kurdyjskiej autonomii w północnym Iraku i utworzeniu Regionu Kurdystanu, jako jednej z federacyjnych części Iraku, a jednocześnie utracie ponad 20 mandatów w drugich parlamentarnych wyborach (15 grudnia 2005), uznali, że wewnętrzne waśnie mogą doprowadzić do zaprzepaszczenia szansy na wymarzoną niezależności. Doszło więc, ku zdziwieniu wszystkich irackich Kurdów, ale przede wszystkim rządów państw ościennych i rządów państw koalicyjnych, do podpisania porozumienia w dniu 21 stycznia 2006 r., pomiędzy przywódcami dwóch najważniejszych kurdyjskich partii w Iraku: Demokratycznej Partii Kurdystanu (KDP, reprezentowanej przez Masuda Barzaniego, obecnego prezydenta Regionu Kurdystanu) i Patriotycznej Unii Kurdystanu (PUK, reprezentowanej przez Dżalala Talabaniego, prezydenta Iraku ((Ha), 2006). Jeszcze w latach 90-tych XX w. partie te prowadziły bratobójczą wojnę (Grigies, 1997, s. 87-89; Lalik, 2009, s. 124-139). Od stycznia 2006 r. wspólnie prowadzą działalność na rzecz stworzenia silnego pod względem gospodarczym regionu autonomicznego.

\section{Charyzmatyczna postać Masuda Barzaniego}

Przywódcy polityczni od najdawniejszych czasów wzbudzają powszechne zainteresowanie. Ich postawy i zachowania wywołują emocje, często powiązane z próbą znalezienia odpowiedzi na pytanie: kim jest ów przywódca i do jakiej kategorii przywódców należy go zakwalifikować? W politologii dokonuje się takiej kategoryzacji (Wiatr, 2008, s. 23-73). Jednakże z niektórymi przywódcami, umieszczeniem ich w odpowiedniej grupie występują trudności. Wśród tych niesklasyfikowanych, a może raczej trudnych do sklasyfikowania przywódców znajdują się politycy kurdyjscy. Jednym z nich jest Masud Barzani, polityk z Bliskiego Wschodu, który wyniósł umiejętności rządzenia narodem $\mathrm{z}$ rodzinnego domu.

Nazwisko Barzani, dla Kurdów, wiąże się z legendarną, pełną charyzmy postacią Mustafy Barzaniego, nieżyjącego już ojca Masuda Barzaniego, obecnego prezydenta RK. Po śmierci Mustafy, Masud przejął prowadzenie założonej przez ojca Demokratycznej Partii Kurdystanu i kontynuuje jego politykę. Dzięki odpowiedniemu wychowaniu, jakie wyniósł z domu, w atmosferze wielkiej polityki i wpajaniu od najmłodszych lat idei poświęcania się dla własnego narodu, a nie tylko rodu czy klanu, podobnie jak jego ojciec, Masud stał się człowiekiem, którego społeczność kurdyjska obdarza ogromnym zaufaniem.

Chociaż na mapie świata nie ma państwa o nazwie Kurdystan, a Region Kurdystanu, to zaledwie niewielki fragment etnicznego Kurdystanu w północnym Iraku, Masudowi 
udało się doprowadzić do uzyskania daleko idącej autonomii dla Kurdów, a także wykreować ten Region na jeden $\mathrm{z}$ istotniejszych w obszarze Bliskiego Wschodu, który w praktyce funkcjonuje jak samodzielne państwo. On sam traktowany jest przez liczących się na świecie polityków jako prezydent niepodległego państwa, jednak w rzeczywistości reprezentuje jedynie region autonomiczny. Mimo, że rządy krajów ościennych wyrażają niechęć do formalnej kurdyjskiej autonomii powstałej w Iraku, i od lat prowadzą systematyczną dyskryminację mniejszości kurdyjskiej zamieszkującej ich kraje, to tempo rozwoju gospodarczego i pozycja, jaką zdobywa Region Kurdystanu pod przywództwem Masuda, zmienia nastawienie owych rządów do Kurdów. Natomiast, jeśli chodzi o Kurdów zamieszkałych na terenach Syrii, Turcji i Iranu, to często traktują Masuda, jak własnego prezydenta, a przecież oficjalnie jest on prezydentem tylko irackich Kurdów i to tylko z Regionu Kurdystanu.

Z rodem Barzanich wiąże się historia ostatniego stulecia w irackim Kurdystanie, ale nie tylko, bowiem wpływy Barzanich rozciagają się na północno-zachodni Iran, południowo-wschodnią Turcję i północno-wschodnią Syrię, a nawet na Zakaukazie. Najważniejszą postacią jest nieżyjący już Mustafa Barzani, największy kurdyjski przywódca, zwany „Ojcem Kurdów”. . Mustafa Barzani za priorytetowy cel postawił sobie zjednoczenie wszystkich zwaśnionych, kurdyjskich plemion oraz partii i stworzenie silnego Kurdystanu. Jego syn Masud kontynuuje politykę ojca i nie chodzi mu jedynie o stworzenie państwa kurdyjskiego, o czym w obecnej sytuacji politycznej trudno mówić, ale o zjednoczenie Kurdów, uświadomienie im ich własnej wartości, ale i tożsamości narodowej.

15 czerwca 2005 r. Masud został zaprzysiężony na prezydenta Kurdystanu. Ma jedną żonę i ośmioro dzieci, zna cztery języki: kurdyjski, perski (farsi), arabski i angielski. Mówi się o nim, że to spokojny, rozważny polityk, chociaż jest również dobrym strategiem wojskowym. W bezpośredniej rozmowie jest miły, konkretny, posiada szeroką wiedzę - również na temat Polski, umie też słuchać ${ }^{8}$. Kurdowie patrzą na swojego przywódcę niemal jak na święty obrazek, bowiem udało mu się stworzyć na obszarze autonomicznym strukturę regionu, który funkcjonuje jak samodzielne państwo. Rola tego przywódcy już została zauważona zarówno przez państwa ościenne, jak i współczesne mocarstwa. Mimo że prezydentem Iraku jest Dżalal Talabani, to postać Masuda Barzaniego wyraźnie wybija się na prowadzenie. O problemach Kurdów i kurdyjskiej federacji rozmawia się nie z prezydentem Iraku, ale z nieformalnym prezydentem nieistniejącego państwa.

Tak więc Kurdowie mają własnego prezydenta, własny parlament, własną 200-tysięczną armię ${ }^{9}, 100$-tysięczną policję ${ }^{10}$, szkolnictwo, a nawet własną politykę gospodarczą

${ }^{7}$ Na temat Mustafy Barzaniego powstało bardzo wiele opracowań. Do jednych z nich zalicza się książka napisana przez jego syna Masuda (Barzani, 2003).

${ }^{8}$ Autorka miała przyjemność osobiście poznać Masuda Barzaniego. W czerwcu 2005 r. przeprowadzila z nim wywiad. W Kurdystanie panuje zwyczaj, że Europejczyk, np. dziennikarz, albo naukowiec ma prawo zwracać się po imieniu nawet do prezydenta. Masud Barzani zwracał się do autorki po imieniu i vice versa.

${ }^{9}$ Informacja podana w wiadomościach: TV Kurdistan 3.02.2011.

${ }^{10}$ Ibidem. 
i własną gospodarkę związaną z wydobyciem ropy naftowej. W Regionie Kurdystanu językiem urzędowym jest kurdyjski, a nie jak w całym Iraku arabski. Młodzi Kurdowie w Iraku uczą się w szkołach arabskiego tylko w kontekście religijnym (czytanie Koranu w innym języku niż arabski jest wśród muzułmanów uznawane za świętokradztwo, a Kurdowie, to w większości muzułmanie). Reasumując, to państwo już istnieje, chociaż nie ma go na mapie świata.

Dowodem rosnącej roli RK w relacjach zewnętrznych stały się zagraniczne wizyty prezydenta Masuda Barzaniego, a także premiera Nechirvana Idrisa Barzaniego, który jest bratankiem Masuda. Wizyta w Białym Domu u George'a W. Busha (2005 r.), w Londynie spotkanie z Tony'm Blairem (2005 r.), audiencje u Benedykta XVI (2005 r. i 2009 r.), spotkanie z Condoleezzą Rize w RK (2006 r.), spotkanie z Barackiem Obamą w Bagdadzie (2009 r.), czy też spotkanie Barzaniego z Obamą w Waszyngtonie (5.04.2012 r.) to tylko niektóre przykłady.

Przywódca kurdyjskiej autonomii przyjmowany jest z honorami należnymi przywódcy samodzielnego państwa, chociaż jest tylko przywódcą jednego regionu w Iraku. Prestiż, jaki zdobyl sobie Masud Barzani wpływa, co prawda na powolną, ale jednak stabilizację rejonu Bliskiego Wschodu. Jeszcze nie wiadomo co stanie się z samym Irakiem i jaka będzie ostateczna wersja kurdyjskiej enklawy, ale pojawiły się pierwsze symptomy złagodzenia stosunków pomiędzy Turcją a $\mathrm{RK}^{11}$.

Należy też nadmienić, że Irak w niezmienionej formie funkcjonuje tylko dzięki Kurdom. Są oni „katalizatorem” pomiędzy od wieków zwaśnionymi sunnitami i szyitami. Przykładem tego są wydarzenia sprzed trzech lat, kiedy to od marcowych (2010 r.) wyborów parlamentarnych do połowy listopada (2010), a więc przez 8 miesięcy Irakijczycy nie potrafili stworzyć nowego rządu. Ten impas w polityce powodował w kraju chaos, zachęcał rebeliantów do ataków terrorystycznych i odstraszał zagranicznych inwestorów. Dopiero, kiedy na arenę polityczną wkroczyli Kurdowie, a konkretnie Masud Barzani, i zaczęli prowadzić indywidualne negocjacje $\mathrm{z}$ obu arabskimi stronami, występując w charakterze poręczycieli, udało się osiaggnąć porozumienie (w nocy z 8 na 9 listopada), na mocy którego został utworzony rząd $z$ dotychczasowym premierem Nurim al-Malikim na czele (Santana, 2010). Sukces Barzaniego, któremu udało się zapobiec rozpadowi Iraku, zauważyły niemal wszystkie rządy świata, poza polskim. Do Kurdystanu zaczęły napływać gratulacje. Jednym z pierwszych gratulujących był prezydent USA Barack Obama.

„Czujemy się dumni, że jesteśmy w stanie odgrywać tak ważną rolę w Iraku. Po tych trudnych rozmowach zaistniała szansa na stworzenie stabilnego irackiego rządu, który ma szansę przetrwać do kolejnych wyborów parlamentarnych przewidzianych na $2014 \mathrm{r}$. Jesteśmy też dumni z tego, że politycy iraccy zdali sobie sprawę, że Kurdowie i Kurdystan są źródłem siły i wsparcia dla reszty kraju”, stwierdził Masud Barzani podczas konferencji prasowej w Bagdadzie, która miała miejsce 12 listopada 2010 r. (Parker, 2010).

\footnotetext{
${ }^{11}$ Ocieplenie stosunków pomiędzy rządem Turcji a rządem RK wynika z pragmatycznego podejścia władz Turcji, bowiem na obszarze RK znajdują się spore zasoby ropy naftowej, które będą transportowane do Europy przez terytorium Turcji w ilości 1 miliona baryłek dzienne do 2015 r. i 2 milionów dzienne do 2019 r. (Lee, 2012).
} 


\title{
3. Stawianie na gospodarkę i tolerancję
}

Mocna gospodarka stała się dla Kurdów priorytetem. Nie jest to łatwe, gdyż jeszcze w 2003 r. kraj był doszczętnie zrujnowany, począwszy od domów, dróg, elektryczności ${ }^{12}$.

\begin{abstract}
„Przez lata w Iraku funkcjonował rząd centralny, który miał silną gospodarkę $i$ dużo pieniędzy. Te pieniądze, w znacznym procencie zarabiane na nas i u nas były wykorzystywane przeciwko naszemu narodowi. Przed interwencją amerykańską z jednej strony mieliśmy blokadę iracką, z drugiej międzynarodową. Nie mogliśmy budować fabryk, rozwijać gospodarki. Do tego Turcy prowadzili przeciwko Kurdom akcję ludobójstwa, nie mieliśmy czasu na rozwijanie się. Na świecie wszyscy poszli do przodu, a my? Dlatego dzisiaj w Kurdystanie stawiamy głównie na sektor prywatny, bo przykładowo system socjalistyczny, upaństwowienie wszystkich sektorów gospodarki nie sprawdził się. Pomagamy więc sektorowi prywatnemu poprzez różne ustawy, bo ten jest bardziej dynamiczny. Zmusza do tworzenia się konkurencji, która daje impuls do kolejnych działań"13.
\end{abstract}

Zaczęto od wznoszenia domów mieszkalnych. W Hawlerze, stolicy RK powstaja dzielnice domów jednorodzinnych, łącznie z dzielnicami zamkniętymi i strzeżonymi, stawia się też bloki - apartamentowce i biurowce, sklepy, mosty, wiadukty, parki, urządzenia sportowe, gmachy ministerstw, szkoły, meczety, kościoły. Buduje się bardzo wiele dróg. Od pierwszych dni września $2010 \mathrm{r}$. stolica posiada nowoczesne lotnisko, zaliczane do jednych z największych na Bliskim Wschodzie, z ponad stu stanowiskami. Nowoczesne lotnisko powstało także w Sulejmaniji. Część autonomiczna ma obecnie dwa międzynarodowe lotniska. Regularne, bezpośrednie loty łączą ten region z 25 miastami Europy, Azji i Bliskiego Wschodu (Giedz, 2011b, s. 85). We wrześniu 2012 r. rozpoczęto budowę trzeciego, międzynarodowego lotniska obok położonego w zachodniej partii RK miasta Duhok. Jej zakończenie przewidziane jest na rok 2015 (Prime Minister).

Miejscowość o nazwie Diana, odległa od stolicy o ok. 100 km na północny wschód, przed interwencją amerykańską była niedużą wioską. Dzisiaj jest to kilkudziesięciotysięczne miasto z filią wyższej uczelni. Podobnie sytuacja wygląda z uniwersyteckim miastem Duhok, które w 2005 r. liczyło kilkadziesiąt tysięcy mieszkańców, a w 2013 było ich prawie 500 tys. (Dahuk).

Jednak gospodarka, to nie tylko infrastruktura. Aby móc rozpocząc i rozwijać produkcję zaczęto wprowadzać gospodarkę wolnorynkową. Jej podstawę stanowią zagraniczni inwestorzy. Z myślą o nich powstało specjalne „Prawo Inwestycyjne Regionu Kurdystanu" (Kurdystan i Polska). Porównując z innymi obszarami Bliskiego Wschodu jest to prawo najbardziej przyjazne dla zagranicznych inwestorów. Mimo konfliktu pomiędzy rządem Turcji a Kurdami, większość inwestorów w RK, poza sektorem naftowym, re-

${ }^{12}$ Do 1991 r. 65\% miejscowości w północnym Iraku zostało zniszczonych. Autorka, wędrując przez te tereny, często pieszo, osobiście widziała kilkaset wiosek i miasteczek składających się nawet nie $\mathrm{z}$ ruin, a z gruzów. To byly zniszczenia z różnych konfliktów, które rozgrywaly się na terenach kurdyjskich w latach 70-tych, 80-tych XX w., a przede wszystkim podczas exodusu Kurdów wiosną 1991 r., którego autorka byla świadkiem.

${ }^{13}$ Fragment wywiadu przeprowadzonego przez autorkę z dr. Kemalem Kirkukim, marszałkiem parlamentu kurdyjskiego w dniu 21 września 2010 r. 
prezentuje firmy tureckie. Jest to interesujące zjawisko, bowiem z jednej strony turecka armia bombarduje tereny kurdyjskie, a nawet wkracza na obce terytorium i to za przyzwoleniem własnego parlamentu ${ }^{14}$, niszcząc $\mathrm{z}$ trudem odtwarzaną infrastrukturę, $\mathrm{z}$ drugiej w sklepach odzieżowych 90\% towaru stanowią ubrania produkcji tureckiej. W $2010 \mathrm{r}$. Turcja eksportowała do Iraku produkty za 7,5 miliardów USD, z tego 70\% produktów trafiło do RK (Kurdistan, s. 60-61). 741 firm tureckich ma swoje bazy w Hawlerze. Codziennie granicę turecko-kurdyjską przekracza ponad 1500 ciężarówek.

W sklepach spożywczych głównymi produktami są wyroby irańskie. Na pytanie, a gdzie podziały się produkty kurdyjskie, które w 2005 r. stanowiły większość towaru w sklepach, słyszy się odpowiedź: „Jeśli nasi sąsiedzi zobacza, że u nas mogą się wzbogacić nie będą niszczyć naszych terenów i naszych ludzi. Chcemy im pokazać, że konflikty można rozwiązywać drogą pokojową. My im pozwolimy zarobić, oni przestaną nam przeszkadzać w rozwijaniu się i tworzeniu demokratycznego kraju"15.

Na temat rozwoju gospodarczego RK powstało wiele opracowań, w tym dwa autorki tej pracy (Giedz, 2008; Giedz, 2011b), więc w niniejszym materiale jest on jedynie zasygnalizowany. Należy jednak wspomnieć, że główną gałęzią gospodarczą RK jest przemysł naftowy. W 2011 r. RK dziennie eksportował 100 tys. baryłek ropy (Kurdistan, s. 72). Wydobycie ropy z roku na rok się zwiększa, a fakt ten nie tylko przyciaga międzynarodowych inwestorów, m.in. takie firmy, jak ExxonMobil, Chevron, Total (Zandi, 2012), ale również wzbudza zainteresowanie ościennych rządów. W 2012 r. eksportowano się z Kurdystanu 140 tys. baryłek ropy dziennie, a w 2013 r. deklarowano zwiększenie eksportu ropy do 250 tys. baryłek dziennie, a może i więcej (Mackey, 2012). Aby dobrze zarządzać regionem i go rozwijać, potrzebne jest dobre wykształcenie, które za rządów partii Baas nie było dostępne dla wszystkich, a poziom nauczania był bardzo niski. Dzisiaj Kurdowie mogą się poszczycić 1,4 mln uczniów i studentów z ponad 5 tys. szkół (Kurdistan, s. 26) ${ }^{16}$.

Na terenach kurdyjskich obok Kurdów od stuleci mieszka kilka narodów, a także społeczności wyznającej różne religie. Przynależność religijna wśród samych Kurdów też jest zróżnicowana, dlatego tolerancja i akceptacje „innego” stały się codziennością. „Nie jest ważne, kto do jakiej religii przynależy. Koran mówi, że wszyscy są równi, nie ma, że jedni są lepsi, a drudzy gorsi. Jesteśmy narodem Kurdystanu"17.

Ta dewiza, a także dbałość o bezpieczeństwo mieszkańców przyczynia się do tego, że RK staje się miejscem schronienia dla wielu mieszkańców, w tym w znacznym stopniu chrześcijan z pozostałych obszarów Iraku. Chrześcijanie do RK przybywają dużymi grupami, głównie z Bagdadu i Mosulu. Ankawa, do niedawna nieduża chrześcijańska dzielnica na peryferiach Hawleru, dzisiaj jest ponad 40 tys. miastem zamieszkałym przez ponad 90\% chrześcijańskich Arabów i Asyryjczyków. Dla owych chrześcijańskich przybyszów, również chrześcijańskich uchodźców z Syrii, rząd kurdyjski buduje osiedla,

${ }^{14} 17$ października $2007 \mathrm{r}$. parlament Turcji przyjął ustawę, która zezwala rządowi na podejmowanie decyzji o militarnym ,ściganiu" partyzantów PKK na terytorium obcego państwa, czyli Iraku (Affek, 2007).

${ }^{15}$ Fragment wywiadu z dr. Kirkukim, op. cit.

${ }^{16}$ Teren RK zamieszkuje ponad $4 \mathrm{mln}$ osób. W szkołach i na uczelniach językiem wykładowym jest kurdyjski $\mathrm{i}$ angielski.

${ }^{17}$ Fragment wywiadu z dr. Kirkukim, op. cit. 
a nawet wioski w różnych regionach autonomii, najczęściej na terenach wcześniejszych chrześcijańskich zasiedleń.

Interesującym przykładem jest wioska Berseve niedaleko Zakho, podzielona na muzułmanów - 55\% i chrześcijan - 45\%, do której przybyło po 2005 r. ponad 300 chrześcijańskich rodzin uciekających przed atakami terrorystycznymi w arabskiej części Iraku. Wszystkie te rodziny otrzymały od rządu kurdyjskiego samodzielne, nowe domy. Wybudowano dla nich również dwa kościoły. W Berseve zamieszkałej przez 800 rodzin znajdują się obecnie 3 kościoły i 1 meczet $^{18}$.

Kurdowie z RK są otwarci na swoich rodaków z innych części Kurdystanu. Sporą grupę imigrantów stanowią Kurdowie tureccy, którzy sprowadzają się do RK, szukając pracy lub przybywają wraz z turecko-kurdyjskimi firmami inwestującymi w autonomii. Specyficzną grupę stanowią kurdyjscy uchodźcy z syryjskiego Kurdystanu ${ }^{19}$.

\section{Region Kurdystanu wobec wydarzeń "Arabskiej Wiosny", z uwzględnieniem syryjskiej rewolucji i mieszkających tam Kurdów}

Wydarzenia zwane „Arabską Wiosną”, jakie miały i mają miejsce w krajach bliskowschodnich wzbudzają spore zainteresowanie Regionalnego Rządu Kurdystanu. Aczkolwiek już dzisiaj wiadomo, że „Arabska Wiosna” utożsamiana jest z „muzułmańską, czy islamską wiosną". Nie ma w niej miejsca dla innych narodów i innych religii, zwłaszcza w wydaniu syryjskim.

Syria, czyli Syryjska Republika Arabska - taką nazwę wprowadził rząd partii Baas - jest krajem wielonarodowym i wieloreligijnym, przez ostatnie kilkadziesiąt lat funkcjonującym pod stałym nadzorem silnie rozbudowanych służb bezpieczeństwa ${ }^{20}$. Ogólnie można powiedzieć, że dzieli się na 4 grupy religijno-narodowe. Do pierwszej zaliczmy Alawitów (Alawici w Syrii, Alewici w Turcji), którzy są zarabizowanymi potomkami ludów śródziemnomorskich, m.in. Fenicjan, ale i Kurdów. Wszyscy związani są z alawizmem, religijnym odłamem wywodzącym się z szyizmu (Danecki, 1997, t. I, s. 335-337). Do niedawna muzułmanie pogardzali Alawitami do tego stopnia, że uznawano ich za wyznawców osobnej religii, a nawet osobną grupę etniczną. Dzisiaj Irańczycy, w większości szyici, utożsamiają ich z szyitami. To z kręgu Alawitów wywodzi się reżimowy rząd Baszara al-Assada. W Syrii ich tereny rozciągają się na zachodzie kraju, wzdłuż wybrzeża Morza Śródziemnego. Są to prowincje Latakkia i Tartus, gdzie znajduje się baza wojsk rosyjskich. Teoretycznie stanowią dość jednolitą grupę, aczkolwiek nie wszyscy z nich popierają reżimową władzę. Alawici mieszkają też w Turcji, stanowiąc kilkunastoprocentowy odsetek mieszkańców tego kraju ${ }^{21}$.

${ }^{18}$ Autorka przebywała w Berseve we wrześniu $2010 \mathrm{r}$.

${ }^{19}$ Autorka przebywała wśród syryjskich uchodźców w czerwcu 2013 r., zarówno w obozie w Domiz, jak i u rodzin wynajmujących mieszkania w różnych regionach RK. W większości byli to Kurdowie. Wedhug danych rządu RK z października 2013 r. przebywalo ich w RK ponad 240 tys. (High-level).

${ }^{20} \mathrm{~W}$ marcu $1963 \mathrm{r}$. władze Syrii na terenie całego kraju wprowadzily stan wyjątkowy, który odwołano dopiero 21 kwietnia 2011 r. (Giedz, 2010, s. 83).

${ }^{21}$ Danecki szacuje tę społeczność mieszkającą tylko na terenie Turcji na około $16-17 \mathrm{mln}$, (Danecki, 1997, s. 336). 
Sunnici, czyli arabscy sunnici zajmują środek kraju. Głównie z powodów religijnych, ale i z chęci przejęcia władzy, nie akceptują Alawitów. Tworzą opozycyjne grupy wobec reżimu. Spośród nich wyróżnia się ugrupowanie zwane Bractwem Muzułmańskim, charakteryzujące się fundamentalizmem religijnym, dążącym, mówiąc w dużym skrócie, do stworzenia jednego, wspólnego narodu muzułmańskiego (Ibidem, t. II, s. 127-129).

Kolejną grupą są Druzowie, zamieszkujący tereny położone na południu od Damasz$\mathrm{ku}$, pomiędzy granicą z Jordanią i Izraelem, głównie w górskim rejonie Hawranu. Nie do końca wiadomo kim są, Arabami, Hebrajczykami...? Wywodzą się z islamu szyickiego, aczkolwiek np. w Izraelu, gdzie również mieszkają, uznawani są za osobny naród z własną religią (Ibidem, t. I, s. 163-172). W ich religii znajdują się elementy wskazujące na połączenia z jezydyzmem. Należałoby jeszcze wspomnieć o chrześcijanach reprezentujących kilkanaście kościołów, w większości wschodnich (Giedz, 2011b, s. 320-323).

Na tle dwudziestomilionowej społeczności syryjskiej wyróżnia się naród Kurdyjski, szacowany na ok. 3,5 mln osób (Giedz, 2012, s. 70). W kontekście Syrii niewiele mówi się o Kurdach, a raczej mówiło, bo sytuacja bardzo się zmienia. Kurdowie zamieszkują północne i północno-wschodnie tereny Syrii. Około 2 mln Kurdów mieszka w rejonie zwanym Dżezria, czyli w prowincji Hassake, w rejonie Kamyszlu i innych mniejszych miast.

Przez lata reżimu Assadów Kurdowie prawie nie angażowali się w działalność polityczną czy opozycyjną, aczkolwiek tworzyli nielegalnie swoje partie. Kurdowie są rozdzieleni na kilka religii i mimo że większość z nich jest sunnitami, to Kurdów nie postrzega się jako grupy religijnej. Część z nich, obecnie szacowana na ok. 350 tys. osób, na początku lat 60 -tych $\mathrm{XX}$ w. została pozbawiona praw obywatelskich, mówi się o nich, że to ludzie bez tożsamości (Giedz, 2002, s. 98-101). Dopiero w kwietniu 2011 r., a więc po rozpoczęciu „Arabskiej Wiosny” w Syrii, rząd Baszra al-Assada, bojąc się rewolucji kurdyjskiej, wydał dekret przywracający syryjskie obywatelstwo ponad 500 tys. osób, które utraciły je w wyniku spisu ludności przeprowadzonego w 1961-1962 r. (The Kurdish Role; Hassino, Tanir, 2012). Dekret ten niestety nie jest respektowany. Kurdowie od lat byli poddawani arabizacji, upokorzeniu, inwigilacji (Giedz, 2012). W Syryjskim Kurdystanie nie było akcji anfal ${ }^{22}$, zabijania bronią chemiczną, bombardowań. W Syrii z Kurdami rozprawiano się najczęściej po cichu i pojedynczo, dlatego większość z nich po prostu się bała.

Powstanie Regionu Kurdystanu w północnym Iraku i jego umacniająca się pozycja w regionie dało syryjskim Kurdom nadzieję na zmianę ich losu, mimo zwiększających się restrykcji stosowanych wobec nich przez władze Syrii (Giedz, 2009, s. 423-437). „Arabska Wiosna” i w jej następstwie syryjska rewolucja wytworzyła wśród Kurdów pozycję wyczekująca. Kurdowie postanowili nie angażować się w nie swoją wojnę, bo, jak wyjaśniali w rozmowach z autorka, zbyt dużo wycierpieli. Kurdowie pamiętają wykorzystywanie ich przez Turków do przeprowadzenia ludobójstwa Ormian w 1915 r., czy też

\footnotetext{
${ }^{22}$ Akcja Anfal, to zakrojona na szeroką skalę akcja wyniszczania Kurdów na terenie Iraku, oparta na 42 paragrafie ustalonego w 1924 r. irackiego prawa, obowiązującego do upadku rządu Saddama Husajna. Zgodnie z VIII Surą Koranu, niewierni, a za takich uznawano Kurdów, mogli być poddawani deportacjom, umieszczaniu w obozach pracy, a nawet pozbawianiu życia. Akcji Anfal było kilka. Pierwsza miała miejsce w 1975 r. (Giedz, 2010, s. 92-96).
} 
namówienie do zaangażowania się w irańską rewolucję i obalenie szacha w 1979 r. Oba te wydarzenia dla Kurdów skończyły się tragicznie ${ }^{23}$. Nie chcą więc popełnić kolejnego błędu. „Ta rewolucja nie uznaje mniejszości w Syrii, ani Druzów, ani chrześcijan, ani Kurdów"24.

O tragicznych wydarzeniach „Arabskiej Wiosny” śpiewa Şivan Perwer, kurdyjski bard, mieszkający na uchodźstwie. To jego pieśni, mówiące o pokoju, również wśród Arabów, przyczyniły się do tego, że Kurdowie zaczęli być postrzegani na równi z Arabami. Może dlatego Syryjski Kurdystan stał się rejonem omijanym przez reżimowe wojska (Gallo, 2012). Chociaż Fund Jomma i Janusz Jartyś uważają, że przekazanie przez rząd Assada władzy Kurdom (Kurdyjskiej Radzie Narodowej w Syrii i PYD - Partii Unii Demokratycznej, łączonej z PKK - Kurdyjską Partią Pracy uznawaną w Turcji za organizację terrorystyczną) na terenach kurdyjskich było chęcią sprowokowania rządu Turcji i wykorzystania narodowych niesnasek do własnych celów (Jomma, Jartyś, 2012).

Mimo wszystko Kurdowie nie przyjmowali pozycji biernej. Wręcz przeciwnie, próbowali przyłączyć się do opozycji syryjskiej, czego przykładem jest wybór Kurda na szefa Syryjskiej Rady Narodowej, po ustąpieniu jej pierwszego przewodniczącego, profesora paryskiej Sorbony Burhana Galjuna. Na nowego szefa SRN, 9 czerwca 2012 r., podczas spotkania syryjskich opozycjonistów w Stambule, wybrano właśnie Kurda, doktora filozofii i historii Abdula Basaida Seyda, byłego nauczyciela z Amudy, 50-tysięcznego miasta, odległego o $30 \mathrm{~km}$ od Kamyszlu, obecnie mieszkającego w Szwecji (Opozycyjna, 2012). Takiego wyboru dokonano może dlatego, że to właśnie Kurdowie w RK dali się poznać, jako ludzie, którzy potrafią rozmawiać z różnymi zwaśnionymi grupami.

Niestety opozycja syryjska była i jest na tyle podzielona, a na dodatek skłania się ku fundamentalizmowi muzułmańskiemu, którego Kurdowie nie akceptują, że syryjscy Kurdowie również zaczęli się dzielić na wiele frakcji. Ich podział i niezdecydowanie zaczęły wykorzystywać władze Turcji, które wykazują dualizm wobec tejże rewolucji. Z jednej strony rząd Turcji daje schronienie syryjskiej opozycji, a przede wszystkim tworzy obozy dla uchodźców syryjskich, w tym również kurdyjskich. Z drugiej, Turcy przerzucają do Syrii najemników wchodzących w skład Wolnej Armii Syryjskiej, a także wspierają ową armię finansowo, powodując brak stabilizacji na terenach zamieszkałych przez Kurdów (Kurdowie walcza). Owa Wolna Armia Syryjska próbuje przejąć tereny kurdyjskie, zwłaszcza te przy granicy iracko-tureckiej, gdzie znajdują się złoża ropy naftowej.

Kurdowie nie chcąc stracić po raz kolejny swojej ziemi zdecydowali się, pod wpływem rozmów z prezydentem Masudem Barzanim, na połączenie wszystkich kurdyjskich partii funkcjonujących w Syrii. 11 lipca 2012 r., w Halerze doszło do spotkania przedstawicieli owych partii z Masudem Barzanim. Wówczas to powstał jeden wspólny opozycyjny blok kurdyjski - Desteya Bilind a Kurd (DBK, Najwyższa Kurdyjska Rada), jednoczący wszystkie partie, której przedstawicielstwa już istnieją w Derek, Kamyszlu,

${ }^{23}$ W tym samym czasie kiedy przeprowadzano czystki wśród ludności ormiańskiej, życie straciło ponad milion Kurdów, w większości Jezydów. Tylko nielicznym grupom udało się uciec na Zakaukazie, m.in. do Armenii czy Gruzji - twierdził prof. Jalile Jalil (Celilę Celîl), kurdyjski historyk z Akademii Nauk w Wiedniu, w rozmowie z autorką 7.06.2011 r.

${ }^{24}$ Wypowiedź Ajuba Saida, kudryjskiego lekarza mieszkającego w Polsce, pochodzącego z Syryjskiego Kurdystanu, 26 września 2012 r. 
Amudzie, Kobani i Afrin (Ateş, 2012; Neriah, 2012). Zawarto też Układ Hawlerski, na mocy którego wszystkie istniejące dotychczas samodzielne kurdyjskie partie w Syrii mają mieć jednakowy udział w DBK i mają zajmować się polityką, bezpieczeństwem i zarządzaniem, czyli administracją. Praktyka jednak wykazuje znaczną przewagę PYD, z czym nie wszyscy Kurdowie chcą się zgodzić.

Niemniej obecnie w wielu regionach Syryjskiego Kurdystanu prawie nie odczuwa się wojny. Niemal na wszystkich budynkach użyteczności publicznej powiewa kurdyjska flaga. W Amudzie pomnik z podobizną prezydenta Assada zamieniono na statuę wolności. W wielu miejscowościach rozpoczęto regularną edukację dotychczas zabronionego języka kurdyjskiego. To Kurdowie, a nie Syryjczycy kontrolują dystrybucję wody, żywności i paliwa, a także to Kurdowie sami zaczęli decydować, a nie wojsko, czy ziemia na danym polu ma leżeć odłogiem, czy być uprawiana ${ }^{25}$. Mają też własne siły bezpieczeństwa, szkoląc się w specjalnie tworzonych obozach w północno-wschodniej Syrii, a także po drugiej stronie granicy, w Regionie Kurdystanu (Parkinson, 2012, A12). W RK istnieją dwa takie obozy szkoleniowe. Dla syryjskich Kurdów „Arabska Wiosna” przestała się liczyć, bo mają własną „Kurdyjską Wiosnę”.

\section{Podsumowanie}

Sytuacja w Syrii i jej nieformalny podział na cztery obszary (Alawitów, Druzów, sunnitów i Kurdów), a w przyszłości być może federacje daje nową szansę Kurdom. Tocząca się odwieczna bitwa pomiędzy sunnitami i szyitami, a właśnie w takich kategoriach należy postrzegać rewolucję w Syrii, nie jest wojną Kurdów, dla których walka o religię nie ma ogóle znaczenia, a jeśli to drugorzędne. Tą szansą jest zdobycie niezależności, ale aby ją osiągnąć potrzebna jest narodowa jedność. To, czy syryjskim Kurdom uda się, to zależy od nich samych, a także od zaangażowania się w tworzenie kurdyjskiej autonomii w Syrii władz Regionu Kurdystanu. Kurdowie twierdzą, że Syria już została podzielona na 4 federacje, ale toczy się walka o granicę tych regionów federacyjnych ${ }^{26}$. Niezależność kurdyjskiego regionu w Syrii jest już faktem dokonanym, chociaż nieformalnym.

Powstała więc interesująca sytuacja, jakby powtórka z lat 90. XX w. w Iraku północnym, kiedy to na mocy rezolucji Rady Bezpieczeństwa ONZ z 1991 r. utworzono nieformalną kurdyjską autonomię. Rodzi się jednak pytanie, czy państwa ościenne na taką samodzielność Kurdom pozwolą? Usankcjonowanie autonomii kurdyjskiej w Iraku wzbudza wiele kontrowersji, zwłaszcza w państwie tureckim. Co prawda rząd RK wypracował już mocne relacje gospodarcze z Turcja, zwłaszcza w kontekście budowy gazociagu przez terytorium Turcji, ale utworzenie drugiego Regionu Kurdystanu, np. z dostępem do morza (kurdyjski region Afrin niemal graniczy z Morzem Śródziemnym), mogłoby zaburzyć tę pozorną stabilność. Nieformalny podział Syrii jest faktem dokona-

\footnotetext{
${ }^{25}$ Zgodnie z obowiazujacymi przepisami dotyczacych syryjskich Kurdów zamieszkującymi Dżezie, rolnicy mogli uprawiać tylko $15 \%$ gruntów ornych, a i tak niemal wszystkie plony zabierało wojsko (Giedz, 2012, s. 78-79).

${ }^{26}$ Rozmowa autorki z Ajubem Saidem, 26 września 2012 r.
} 
nym, ale jednoczenie się Kurdów, współpraca między nimi, i to w całym rejonie, wzbudza strach w państwach ościennych.

Jednocześnie dobrze rozwijający się eksperyment polityczny, jakim jest realizowanie demokracji na wzór zachodni w RK, pozwala pozytywnie postrzegać Kurdów. Joanna Bocheńska uważa, że Kurdowie mogą być ważnym pomostem w relacjach z mniejszościami religijnymi (np. chrześcijanami), zwłaszcza że takie zadanie stawia przed współczesną kurdyjską ideą narodową wielu kurdyjskich pisarzy i intelektualistów, jak chociażby Mehmed Uzun (Bocheńska, 2012, s. 3-4). Zważywszy na świecki charakter nieformalnego kurdyjskiego państwa w północnym Iraku, a także niechęć do ideologii fundamentalizmu muzułmańskiego, mogą tworzyć zaporę przed jego rozprzestrzenianiem się. Jak sądzi Hiwa Zandi, mogą też odgrywać istotną rolę w utrzymaniu bezpieczeństwa w regionie, a tym samym stać na straży bezpieczeństwa interesów zachodnich na Bliskim Wschodzie, a w szczególności bezpieczeństwa Izraela (Zandi, 2012). Posiadając ogromne zasoby ropy naftowej, gazu i wielu minerałów, jak ruda żelaza, miedź, magnez, złoto, czy kamienie ozdobne, w tym wiele rodzajów marmurów, są regionem wzbudzającym ogromne zainteresowanie państw zamożnych, głównie zachodnich. Dobrze prosperująca gospodarka daje gwarancję dobrej współpracy, a tym samym obopólnego bogacenia się, jeśli dzieje się to bez konfliktów zbrojnych.

Oczywiście Bliski Wschód nie należy do spokojnych regionów. Kurdowie właśnie teraz mają szansę stać się ważnym graczem na międzynarodowej scenie politycznej i gospodarczej. Czy im się to uda? Mają szansę, o ile będą postępować roztropnie, a przede wszystkim będą zjednoczeni, bo kolejnej szansy może już nie być.

\section{Bibliografĩa}

Affek M. (2007), Konflikt o iracki Kurdystan, „Polish News”, 14.11., http://www.polishnews.com/article,45,konflikt-o-iracki-kurdystan.html, 20.11.2007.

Ateș H. (2012), Esad'in 'Kürt kartı' Barzani'ye geçti, 13.07., SABAH, http://www.sabah.com.tr/ Gundem/2012/07/13/esadin-kurt-karti-barzaniye-gecti, 1.12.2012.

Barzani M., Ferhadi A. (2003), Mustafa Barzani and the Kurdish Liberation (1931-1961), New York.

Bedirxan C. A. (1997), De la question Kurde, Avesta, Istanbul.

Bocheńska J. (2011a), Między ciemnościq i świattem. O kurdyjskiej tożsamości i literaturze, Księgarnia Akademicka, Kraków.

Bocheńska J. (2011b), Turcja wobec kryzysu syryjskiego, 19.12., http://www.stosunkimiedzynarodowe.info/artykul,1184,Turcja_wobec_kryzysu_syryjskiego, 7.10.2013.

Bocheńska J. (2012), Kurdowie wobec arabskiej wiosny, „Biuletyn Opinie” FAE, nr 13, 10.07.2012. $\mathrm{http} / / /$ fae.pl/biuletynopiniefaekurdowiewobecarabskiejwiosny.pdf, 7.10.2013.

Constitution of the Republic of Turkey (1982), http://www.ilo.org/wcmsp5/groups/public/---ed protect/---protrav/---ilo_aids/documents/legaldocument/wcms_127495.pdf, 7.10.2013.

Dahuk, http://pl.wikipedia.org/wiki/Dahuk, 7.10.2013.

Danecki J. (1997), Podstawowe wiadomości o islamie, Dialog, Warszawa 1997, t. I.

Dorin B. (2005), Les Kurdes: destin hérö̈que, destin tragique, Lignes de repères, Paris.

Dzięgiel L. (1992), Węzel Kurdyjski, Kultura, Dzieje, Walka o przetrwanie, Universitas, Kraków.

Gallo C. (2012), The Remapping of the Middle East, Assyrian International News Agency, 31.08, http://www.aina.org/news/20120831000826.htm, 1.12.2012. 
Ghassemlou A. R. (1969), Kurdystan i Kurdowie, Książka i Wiedza, Warszawa.

Giedz M. (2002), Węzet Kurdyjski, Dialog, Warszawa.

Giedz M. (2008), Gospodarka Kurdystanu, w: Afryka, Azja, Ameryka Lacińska, Warszawa, t. 84.

Giedz M. (2009), Wplyw przemian politycznych i gospodarczych w Regionie Kurdyjskim pólnocnego Iraku na sytuacje Kurdystanu Syryjskiego, w: Ekonomiczne i polityczne wyzwania we wspótczesnym ladzie globalnym, red. M. Giedz, A. R. Kozłowski, R. Majewski, CeDeWu. Warszawa, s. 423-437.

Giedz M. (2010), Kurdystan, bez miejsca na mapie, Bernardinum, Pelplin.

Giedz M. (2011a), Kurdowie i ich religia, a dqżenia do niepodlegtości, w: Dialog kultur, cywilizacji i religii, red. H. Czakowska, M. Kuciński, Wydawnictwo Kujawsko-Pomorskiej Szkoły Wyższej w Bydgoszczy, Bydgoszcz, s. 320-323.

Giedz M. (2011b), Przemiany spoteczne, polityczne i gospodarcze w federacyjnym regionie Kurdystanu Irackiego, w: Ekonomiczne i spoleczno-polityczne problemy wspólczesnej gospodarki, red. J. Jaworski, CeDeWu, Warszawa.

Giedz M. (2012), Kurdystan Syryjski i zamieszkujacy go Kurdowie, „Przegląd Narodowościowy”, nr 1.

Grigies A. (1997), Sprawa kurdyjska w XX wieku, Dialog, Warszawa.

(HA), Talabani, Barzani agree to one Kurdistan government (2006), KRG (Kurdistan Regional Government), 21 Jan., http://www.krg.org/articles/detail.asp?lngnr=12\&smap= $02010200 \& \mathrm{rnr}=73 \& \mathrm{kanr}=, 15.09 .2012$.

Hassino O., Tanir I. (2012), The Decisive Minority: The Role of Syria's Kurds in the Anti-Assad Revolution, A Henry Jackon Society Raport, http:/www.scpss.org/libs/spaw/uploads/files/Reports/03-2012_Henry_Jackson_Soc_Rpt_re_Role_of_Syr_Kurds.pdf, 7.12.2012.

High-level Iraqi delegation calls for more assistance for Syrian refugees at Geneva conference (2013). 6.10., http://www.krg.org/a/d.aspx?s=010000\&l=12\&a=49318, 7.10.2013.

Iraqi Constitution (2005), http://www.uniraq.org/documents/iraqi_constitution.pdf, 10.12.2009.

Jomma F. (2001), Kurdowie i Kurdystan, Wydawnictwo L\&L i DJ, Gdańsk.

Jomma F., Jartyś J. (2012), Syria w obliczu upadku reżimu i dekompozycji państwa, 2.09., http://kalkomanii.kagero.pl/analizy-felietony-2/1934-syria-w-obliczu-upadku-rezimu-i-dekompozycji-panstwa, 10.09.2012.

Jureńczyk L. (2010), Polska misja w Iraku, Implikacje dla Polski i Iraku, Wydawnictwo Kujawsko-Pomorskiej Szkoły Wyższej w Bydgoszczy, Bydgoszcz.

Katzman K. (2006), Iraq: Elections, Government, and Constitution, November 20, http://fpc.state.gov/documents/organization/76838.pdf, 15.09.2012.

Kurdistan: Invest in Democracy 2011, Kurdistan Regional Government, http:/www.krg.org/uploads/ documents/Kurdistan_Investment_Guide_2011.pdf, 16.09.2012.

Kurdistan Referendum Movement-International Committee (2005), 98 percent of the people of South Kurdistan vote for independence, KurdishMedia, http://www.kurdmedia.com/article.aspx?id=6235, 15.09.2012.

Kurdowie walczq przeciwko Wolnej Armii Syryjskiej (2012), portal Geopolityka.org Stowarzyszenia Europejskiego Centrum Analiz Geopolitycznych, http://geopolityka.org/syria-2012/ 1882-kurdowie-walcza-przeciwko-wolnej-armii-syryjskiej, 7.12.2012.

Kurdystan i Polska (2011), http://bashi.pl/mozliwosci/, 7.10.2013.

Lalik K. (2009), Kurdystan Iracki u progu XXI wieku, Księgarnia Akademicka, Kraków.

Lee J. (2012), KRG planning $1 m$ bpd Pipeline to Turkey, Iraq Business News, 4.10., http://www.iraq-businessnews.com/2012/10/04/krg-planning-1m-bpd-pipeline-to-turkey/, 1.12.2012.

Mackey P. (2012), Update 1-Kurdistan sees oil exports jumping in 2013, 18.09., http://in.reuters.com/ article/2012/09/18/kurdistan-oil-idINL5E8KINOY20120918, 3.12.2012. 
Mehmud S. (2012), Desteya bilinda kurdî nüneratiya me dike, 30.07., „Evropress”, http://www.evropress.org/kurdi/in 1.php?page=heremunevdewleti\&id=1890, 7.12.2012.

Meiselas S. (2008), Kurdistan in the Shadow of History, University of Chicago Press, Chicago.

Neriah J. (2012), Kurdistan: The Next Flashpoint Between Turkey, Iraq, and the Syrian Revolt, 5.08., $\mathrm{http}: /$ jcpa.org/article/the-future-of-kurdistan-between-turkey-the-iraq-war-and-the-syrian-revolt/, 7.12.2012.

Nielubowicz B. (1979), Irak, KAW, Warszawa.

Opozycyjna Syryjska Rada Narodowa na nowego przewodniczacego (2012), "Gazeta Prawna”, 10 czerwca, http://www.gazetaprawna.pl/wiadomosci/artykuly/623718,opozycyjna_syryjska_rada_narodowa_ma_nowego_przewodniczacego.html, 17.09.2012.

Parker N. (2010), LA Times interview with President Barzani, „Los Angeles Time”, 15 Nov., $\mathrm{http}: / / \mathrm{www} . \mathrm{krg}$. org/articles/detail.asp?lngnr=12\&smap=02010200\&rnr=73\&anr=37803, 21.11.2010.

Parkinson J. (2012), Syria's Kurds Build Enclaves as War Rages, „The Wall Street Journal”, 3.10., s. A12.

Prime Minister hosts groundbreaking for Duhok International Airport (2012), 24 Sept., http://www.krg.org/a/d.aspx?l=12\&a=45353, 3.12.2012.

Santana R. (2010), Iraq has deal to form a new government, „The Spokesman-Review”, 11.11., http://www.spokesman.com/stories/2010/nov/11/iraq-has-government-deal/, 1.12.2012.

Talabani elected as Iraqi president (2005), „The Guardian”, 6 April, http://www.guardian.co.uk/ world/2005/apr/06/iraq, 15.09.2012.

The Kurdish Role in the Syrian Revolution (2012), The Damascus Bureau, 16.09., http://www.damascusbureau.org/? $\mathrm{p}=2924,7.12 .2012$.

Treaty of Peace with Turkey signed at Lausanne July 24, 1923, http://wwi.lib.byu.edu/index.php/ Treaty_of_Lausanne, 11.11.2011.

Tripp Ch. (2009), Historia Iraku, Książka i Wiedza, Warszawa.

Wiatr J.J. (2008), Przywództwo polityczne, studium politologiczne, Wydawnictwo Wyższej Szkoły Humanistyczno-Ekonomicznej w Lodzi, Łódź.

Zandi H. (2012), The New Middle East Political Dynamic and the Kurds, Ekurd.net, 3.08., http://www.ekurd.net/mismas/articles/misc2012/8/state6401.htm, 29.08.2012.

\section{Summary}

\section{Kurds in the Contemporary Societies in the Middle East}

The Middle East is a region characterized by huge diversity in terms of religion and ethnicity, as well as nationality. In this Middle Eastern melting pot of societies the Kurds stand out as a nation estimated at 45 million people who were ignored until the tragedy that occurred in the spring of 1991. Before the American intervention in Iraq, the Kurds in all four countries in which they happened to live, were treated as second class citizens. 2003 was a breakthrough, marking the beginning of the Kurds being perceived as a nation which has a right to self-determination. The events after 2003 led to the bizarre situation, in which a marginal population became an important partner on the international political arena. In Iraq the Kurds play the role of a catalyst among discordant Muslim groups. In the context of the „Arab Spring" and events in Syria, they are a bargaining card for the Turkish and Syrian governments, but simultaneously the Kurds are entrusted with integration activities. An extremely interesting situation has arisen. This formerly humiliated community has started to become a respected nation which is able to resolve conflicts in the Middle East.

Key words: Kurdistan, Kurds, Kurdistan Region, Barzani, Middle East, Syrian Revolution 